\title{
Blev templet på Garizim bygget med templet i Jerusalem som forbillede?
}

\author{
Professor mso, ph.d. \\ Anne Katrine de Hemmer Gudme, Københavns Universitet
}

\begin{abstract}
Was the Yahweh temple on Mount Gerizim modelled after the temple in Jerusalem? This question is important for our understanding of the sanctuary on Mount Gerizim and the people who worshipped there; if the Gerizim temple was modelled after the Jerusalem temple the argument in favour of the Gerizim cult as derived from the cult in Jerusalem is strengthened. On the other hand, if no such connection can be demonstrated convincingly one must look elsewhere for the answer to the question of Samaritan origins. The present article gives a brief introduction to the relationship between early Judaism and early Samaritanism, or rather Southern and Northern Yahwism, followed by a presentation of Mount Gerizim and the excavations that were recently carried out there. Finally I shall turn to the theory that the temple on Mount Gerizim was modelled after the Jerusalem temple, which has recently been recast by Dr Yitzhak Magen. I conclude that the archaeological remains from the Persian period sanctuary on Mount Gerizim offer no evidence that this temple was modelled on the temple in Jerusalem.
\end{abstract}

Keywords: Mount Gerizim - temple - Jerusalem - Ezekiel - cult - Persian period - Josephus.

Blev Jahvetemplet på Garizim bygget med templet i Jerusalem som forbillede? Svaret på dette spørgsmål har afgørende betydning for vor forståelse af helligdommen på Garizim og de mennesker, der tilbad deres Gud dér. Hvis templet på Garizim virkelig blev opført med Jerusalemtemplets grundplan som forbillede, styrker det teorien om, at kulten på Garizim er afledt af, og udspringer fra, tempelkulten i Jerusalem. Hvis en sådan forbindelse derimod ikke kan påvises, styrker det snarere teorien om en uafhængig eller sågar primær nordlig kulttradition.

I det følgende vil jeg først give en kort introduktion til den ovennævnte problemstilling, nemlig forholdet mellem tidlig jødedom og tidlig samaritanisme, eller snarere sydlig og nordlig Jahvisme. Dernæst vil jeg give en sammenfatning af de udgravninger, der blev afsluttet på Garizim i 2006, og de fund, de har frembragt. Til slut vil jeg vende mig mod spørgsmålet om Garizimtemplets afhængighed af 
templet i Jerusalem, idet dette afhængighedsforhold er blevet hævdet på ny af Yitzhak Magen, som har ledet de seneste udgravninger på Garizim. ${ }^{1}$

\section{Samaritanisme og jødedom}

Helt overordnet er jagten på samaritanismens oprindelse et forsøg på at finde en forklaring på, hvordan to religioner, samaritanismen og jødedommen, der i dag af både sig selv og andre opfattes som to selvstændige religioner, trods alt har så meget til fælles i forhold til helligtekster, traditioner og ritualer. ${ }^{2}$ Både samaritanismen og jødedommen praktiserer monoteisme, billedforbud, omskærelse, overholdelse af Sabbatten og synagogegudstjeneste. De fejrer også de samme fester og helligdage i overensstemmelse med Pentateuken, om end med to forskellige kalendersystemer. Desuden har de to religioner det til fælles, at to ikke væsentligt forskellige udgaver af Petateuken indgår i deres samling af helligtekster. ${ }^{3}$ På et eller andet tidspunkt opstod der fjendskab, eller i hvert fald uenighed, mellem jøder og samaritanere. Det kan man udlede af $\mathrm{fx}$ Johannesevangeliet 4,20, hvor den samaritanske kvinde siger til Jesus: "Vore fædre har tilbedt Gud på dette bjerg [Garizim], men I siger, at stedet, hvor man skal tilbede ham, er i Jerusalem". Det vil sige, at det i hvert fald i begyndelsen af det 2. årh. e.Kr. var almindeligt kendt, at der var uenighed blandt

1. Det er med stor glæde og taknemmelighed, at jeg dedikerer denne artikel til Niels Peter Lemche i anledning af hans 70 -års fødselsdag. Niels Peter har om nogen lært mig at være nysgerrig og kritisk, og uden hans altid blide og vise vejledning ville jeg finde frem til langt færre og ringere svar på mine endeløse spørgsmål, end jeg rent faktisk gør. Artiklen er en revideret udgave af et foredrag, jeg holdt på konferencen "The Other Temples” i Dublin i maj 2012. Jeg vil gerne takke arrangørerne og de øvrige deltagere for god og konstruktiv respons og diskussion. Desuden vil jeg takke min anonyme fagfællebedømmer for meget nyttig feedback.

2. Dette afsnit bygger på et tilsvarende lidt længere afsnit, "The Yahwists on Mount Gerizim", i Anne Katrine de Hemmer Gudme, Before the God in this Place for Good Remembrance: A Comparative Analysis of the Aramaic Votive Inscriptions from Mount Gerizim (Berlin: De Gruyter 2013), 54-65.

3. Richard J. Coggins, Samaritans and Jews: The Origins of Samaritanism Reconsidered (Oxford: Basil Blackwell 1975), 131-138; Reinhard Pummer, "Samaritan Rituals and Customs", Crown (1989), 650- 690; Pummer (2010), 15-16; Alan D. Crown, "Redating the Schism between the Judaeans and the Samaritans", JQR 82 (1991), 17-50 (20-21). For en introduktion til den samaritanske kalender se S. Powels, "The Samaritan Calendar and the Roots of Samaritan Chronology", Crown (1989), 691-742; Gary N. Knoppers, "Mt. Gerizim and Mt. Zion: A study in the early history of the Samaritans and Jews", SR 34 (2005), 309-337 (313-314). Jeg vil komme nærmere ind på den Samaritanske Pentateuk nedenfor. 
jøder og samaritanere om, hvor det rette kultsted burde ligge. ${ }^{4}$ Det er dog omstridt, hvornår og hvorfor de afgørende forskelle på jøder og samaritanere opstod, og derfor er jagten på samaritanismens oprindelse også ofte forbundet med jagten på en dato for det såkaldte samaritanske skisma. ${ }^{5}$ Traditionelt har man knyttet dette skisma til datoen for opførslen af templet på Garizim. Men nu, hvor der er rejst alvorlig tvivl om omfanget og effekten af et jerusalemitisk forsøg på kultcentralisation, har dateringen af skismaet rykket sig tættere og tættere på datoen for ødelæggelsen af templet på Garizim i slutningen af det 2. årh. f.Kr. ${ }^{6}$

Spørgsmålet om samaritanismens oprindelse er nært forbundet med spørgsmålet om den Samaritanske Pentateuks (SP) tilblivelse. SP nåede Europa i det 17. årh. via den samaritanske menighed i Damaskus. I dag findes der godt og vel 750 SP-manuskripter. ${ }^{7}$ Det ældste af disse manuskripter kan dateres til det 9. årh. e.Kr., men størstedelen af SP-manuskripterne stammer fra slutningen af det 15. årh. ${ }^{8}$ Det fremføres ofte, at SP indeholder rundt regnet 6000 afvigelser fra den Masoretiske Tekst (MT). ${ }^{9}$ I sin nuværende form er SP en udgave af Toraen, der indeholder en række ideologiske elementer, der er karakteristiske for samaritanismen. Disse særligt samaritanske elementers

4. Bob Becking, "Do the Earliest Samaritan Inscriptions Already Indicate a Parting of the Ways?", Judah and the Judeans in the Fourth Century B.C.E., red. Oded Lipschits m.fl. (Winona Lake: Eisenbrauns 2007), 213-222 (213).

5. Reinhard Pummer, "The Samaritans and their Pentateuch", The Pentateuch as Torah: New Models for Understanding Its Promulgation and Acceptance, red. Gary N. Knoppers \& Bernhard M. Levinson (Winona Lake: Eisenbrauns 2007), 237-269 (247-251).

6. Francis Schmidt, How the Temple Thinks: Identity and Social Cohesion in Ancient Judaism (Sheffield: Sheffield Academic Press 2001), 116-131; Melody D. Knowles, Centrality Practiced: Jerusalem in the Religious Practice of Yehud \& the Diaspora in the Persian Period (Atlanta: SBL 2006), 19-53; Cristophe Nihan, "The Torah between Samaria and Judah: Shechem and Gerizim in Deuteronomy and Joshua", Knoppers \& Levinson (2007), 187-223 (190). Magnar Kartveit (The Origin of the Samaritans (Leiden: Brill 2009), 10, 251) skriver, at i det øjeblik templet på Garizim er bygget, da kan man tale om samaritanere. Kontra dette synspunkt se Pummer (2007), 250: "With regard to the question of the origin of the Samaritans, we should underline the fact that the existence of a Samaritan temple on Mount Gerizim was not a sufficient reason for the separation between the YHWH worshippers in Jerusalem on the one hand and the YHWH worshippers in the region of Samaria on the other". 7. Alan D. Crown, Samaritan Scribes and Manuscripts (Tübingen: Mohr Siebeck 2001), 13.

8. Robert T. Anderson, "Samaritan Pentateuch: General Account”, Crown (1989), 390-396.

9. Dette estimat er for nyligt blevet kritiseret af Reinhard Pummer, (2007, 241243), som anfører, at beregningen er forældet og baseret på utilstrækkeligt materiale. Pummer følger i stedet Abraham Tal, ifølge hvem antallet af forskelle på MT og SP reelt er ukendt. 
funktion er primært at identificere Garizim som det rette kultsted..$^{10}$ Efter fundet af Dødehavsskrifterne er det blevet klart, at de ideologiske elementer i SP tilhører et ganske overfladisk og sent lag i teksten, og at den underliggende teksttradition, den såkaldt præ-samaritanske tekstgruppe, også blev brugt og cirkuleret i Yehud..$^{11}$ Man går således ud fra, at SP er en bearbejdning af en udbredt tekstlig tradition, der var kendt både i Samaria og i Yehud i den hellenistiske periode. Der er så småt ved at være enighed om, hvornår denne bearbejdning må have fundet sted; de fleste forskere daterer SP til det andet eller første årh. f.Kr. ${ }^{12}$ De Jahvedyrkende grupper i Samaria og Yehud ser altså

10. SP-udgaven af Dekalogen har MTs første bud som overskrift, og tilføjer så i stedet et tiende bud (Exod 20,17b og Deut 5,18b), som er en kombination af Deut 11,29a, Deut 27,2b-3a, Deut 27,4a, Deut 27,5-7 og Deut 11,30 i den nævnte rækkefølge. Halvverset fra Deut 27,4a har Garizim og ikke Ebal, som der står i MT, og hele det samaritanske tiende bud beordrer israelitterne til at bygge et alter på Garizim, når de kommer ind i landet. Der er ingen af de ideologiske elementer i den præ-samaritanske tekstgruppe blandt Dødehavsskrifterne (se nedenfor). Fx i 4QPaleoExod ${ }^{\mathrm{m}}$, 4Q158 og 4QDeut ${ }^{\mathrm{n}}$, som alle indeholder Dekalogen, er det tiende bud, der befaler et alter på Garizim, ikke med i teksten. Se Adrian Schenker, “Textgeschichtliches zum Samaritanischen Pentateuch und Samareitikon: Zur Textgeschichte des Pentateuchs im 2. Jh. V.Chr.", Samaritans: Past and Present. Current Studies, red. Menachem Mor \& Friedrich V. Reiterer (Berlin/New York: De Gruyter 2010), 105-121 (106); Esther Eshel \& Hanan Eshel, "Dating the Samaritan Pentateuch's Compilation in Light of the Qumran Biblical Scrolls", Emanuel: Studies in Hebrew Bible, Septuagint and Dead Sea Scrolls in Honor of Emanuel Tov, red. Shalom M. Paul m. fl. (Leiden: Brill 2003), 215-240 (220); Pummer (2007), 244. Det kan dog ikke udelukkes, at dette fravær skyldes tekstens noget fragmenterede tilstand, se Hjelm (2000), 92. Men det kan heller ikke udelukkes, at i hvert fald nogle af de såkaldt ideologiske elementer i SP hverken er sene eller en samaritansk tilføjelse til teksten. Fx Deut 27,4, hvor SP og Vetus Latinas "Garizim” formodentlig er ældre end MTs "Ebal", se Reinhard Kratz, "Temple and Torah: Reflections on the Legal Status of the Pentateuch between Elephantine and Qumran", Knoppers \&. Levinson (2007), 77-103 (100-101); se også James H. Charlesworth, "The Qumran Fragment of Deut. 27:4-6 - Building the Altar of the Almighty on Mount Gerizim - Declared Authentic", A.B.-The Samaritan News, 1059-1060 (2010) (100-90).

11. Den præ-samaritanske tekstgruppe kaldes også harmoniserende eller protosamaritansk. Jeg følger Emanuel Tov i brugen af præ-samaritansk: "Because the Samaritan Pentateuch was largely based on a textual tradition that was extant in Ancient Israel, the descriptive name 'Samaritan' is almost irrelevant. The content and typological characteristics of this text were already found in the pre-Samaritan texts found in Qumran, that is, in the ancient nonsectarian texts upon one of which the Samaritan Pentateuch was based. These texts are also named proto-Samaritan, but since that term is often mistakenly interpreted to mean that these early texts contained the beginnings of Samaritan features, the term pre-Samaritan is preferable" (Emanuel Tov, Textual Criticism of the Hebrew Bible, (Minneapolis: Fortress Press $\left.\left.{ }^{2} 2001\right), 81\right)$.

12. Pummer (2007), 246-247; Eshel and Eshel (2003), 239-240; Schenker (2010), 118. Alan D. Crown (1991, 47-50) daterer SP så sent som det 3. eller 4. årh. e.Kr.. Crown $(1991,42)$ skriver: "Throughout the first century the Samaritans were no 
ud til at have delt og udviklet deres religiøse tekster indtil et relativt sent tidspunkt, og der er således intet i udviklingen af de præ-samaritanske tekster - hverken indholdsmæssigt eller i forhold til geografisk fordeling - der indikerer, at de repræsenterer en særlig nordlig tradition, der var tekstligt afhængig af en ældre sydlig tradition. Derfor bør man være åben for muligheden for, at teksttraditionen eller i hvert fald dele af den har spredt sig fra Nord mod Syd, i stedet for altid nærmest rutinemæssigt at gå ud fra, at det er den modsatte bevægelse, der er tilfældet, og derved give Jerusalem en automatisk særstatus. ${ }^{13}$

Forskningen i samaritanismens oprindelse kan lidt firkantet opdeles i to yderpositioner, som Lester L. Grabbe har kaldt for henholdsvis "den polemiske" og "den apologetiske": ${ }^{14}$ 1) Samaritanismen opstod som en gren eller ligefrem en sekt, der udsprang fra jødedommen, og 2) samaritanisme er den uafbrudte fortsættelse af jahvereligionen (jahvisme) i Nordriget, Israel. ${ }^{15}$

Det er karakteristisk for det polemiske synspunkt, nemlig at samaritanismen er en jødisk sekt, at tilskrive en vis grad af historisk troværdighed til beretningen om samaritanernes oprindelse i 2 Kong 17 og til Josefus' brug af denne passage i Antiquitates 9.288-91. ${ }^{16}$ Ifølge

less Jews than the Essenes and the early Christians, Jews bound by the Torah, both oral and written, and a form of the written Torah at that which was well established and is represented at Qumran (4Q Palæo Ex ${ }^{\mathrm{m}}, 11 \mathrm{Q}$ Palæo Lev) among types of the MT and types of the LXX".

13. Jf. Ingrid Hjelms artikel i dette nummer af DTT; Kratz (2007) 98-99; Ingrid Hjelm, "Samaria, Samaritans and the Composition of the Hebrew Bible", Mor \& Reiterer (2010), 91-103 (95, 98-99); Hjelm, "Changing Paradigms: Judean and Samarian Histories in Light of Recent Research", Historie og Konstruktion. Festskrift til Niels Peter Lemche i anledning af 60 airs fodselsdagen den 6. september 2005, red. Mogens Müller \& Thomas L. Thompson (København: Museum Tusculanum 2005), 161-179. Christophe Nihan ((2007), 191) formoder, at Pentateuken blev samlet i Jerusalem, men at den var "intended to be adopted by Yahwists in Samaria, as well, from the very time of its inception" (kursiv i originalen).

14. Lester L. Grabbe, "Israel's Historical Reality after the Exile", The Crisis of Israelite Religion: Transformation of Religious Tradition in Exilic and Post-Exilic Times, red. Bob Becking \& Marjo C. A. Korpel (Leiden: Brill 1999), 9-32.

15. Se Reinhard Pummer, "Samaritanism: A Jewish Sect or an Independent Form of Yahwism?”, Mor \& Reiterer (2010), 1-24, for en god og aktuel introduktion til spørgsmålet om samaritansk oprindelse. Ingrid Hjelm, The Samaritans and Early Judaism: A Literary Analysis (Sheffield: Sheffield Academic Press 2000), 13-75, indeholder en meget nyttig forskningsgennemgang. Se også Ingrid Hjelm, "What do Samaritans and Jews have in Common? Recent Trends in Samaritan Studies", Currents in Biblical Research 3 (2004b), 9-59. Alan D. Crown (red.), The Samaritans (Tübingen: Mohr Siebeck 1989), indeholder ligeledes en meget nyttig introduktion til studiet af samaritanerne med artikler der omhandler historie, arkæologi, teologi, liturgi m.m.

16. Pummer (2010), 1-5 med henvisninger; Hjelm (2000), 13ff. med henvisninger; Menachem Mor, "Samaritan History: The Persian, Hellenistic and Hasmonaean 
2 Kong 17,24-41 bragte kongen af Assyrien en række folkeslag fra Babylon, Kuta, Avva, Hamat og Sefarvajim til Samaria, så de kunne befolke de byer, israelitterne havde efterladt, da de selv blev ført til Assyrien (v.6). Den nye befolkning i Samaria forsøgte at tilbede Jahve. De bad sågar om at få en af de israelitiske præster, der var blevet deporteret, sendt tilbage, så han kunne lære dem at udføre kulten korrekt. Men ikke desto mindre udviklede kulten på Garizim sig til et synkretistisk miskmask af Jahvedyrkelse blandet med folkeslagenes egne religioner. "Disse folk frygtede Jahve", står der i 2 Kong 17:41, "men de dyrkede deres gudebilleder, og deres børn og børnebørn gør den dag i dag sådan, som deres fædre gjorde". I Josefus' gengivelse af 2 Kongebog 17 i Antiquitates 9.288-91 identificerer han indbyggerne i Samaria med de folk, der kom fra Kuta ${ }^{17}$, og som kaldes kutæere på hebraisk og samaritanere på græsk. ${ }^{18}$ Samaritanerne minder måske nok om jøder, men ifølge 2 Kongebog 17 og Ant 9.288-91 er de udlændinge og fremmede. Kernen i det polemiske synspunkt er, at Samaritanismen er et fremmedelement og en bearbejdning af jødedommen i dens "rene" form. Dette synspunkt tildeler uvægerligt samaritanismen en sekundær status i forhold til jødedommen.

Det andet, apologetiske, synspunkt, at samaritanisme er en direkte fortsættelse af gammel israelitisk religion, stemmer i grove træk overens med samaritanernes egne overleveringer. Ifølge den Samaritanske Krønike er samaritanerne efterkommere af de israelitter, der forblev trofaste og blev på Garizim, i stedet for at følge den frafaldne præst, Eli, til Shilo. Tempelkulten i Jerusalem anses for at være det endelige resultat af Elis frafald. ${ }^{19}$ Det apologetiske synspunkt forudsætter altså, at beretningen i 2 Kongebog 17 er unøjagtig, når den hævder, at hele befolkningen i Samaria blev deporteret til Assyrien. Kun eliten blev sendt i eksil, og nogle fremmede folk blev bragt til området for at bosætte sig, men den indfødte befolkning blev, hvor den var, og dens daglige liv, kultur og religion fortsatte stort set uændret. ${ }^{20}$ Dette syns-

Period", Crown (1989), 1-18 med henvisninger.

17. En by i Mesopotamien. Det nuværende Tell Ibrahim, der ligger nord for Babylon.

18. Reinhard Pummer, The Samaritans in Flavius Josephus (Tübingen: Mohr Siebeck 2009), 67-76; Hjelm (2010a), 93-94.

19. Grabbe (1999), 14-15 med henvisninger; Moses Gaster, The Samaritans: Their History, Doctrines and Literature, The Schweich Lectures 1923 (London: Humphrey Milford 1925), 7ff.

20. Gary N. Knoppers, "In Search of Post-Exilic Israel: Samaria after the Fall of the Northern Kingdom", In Search of Pre-Exilic Israel, red. John Day (London: T\&T Clark 2004), 150-180; Pummer (2007), 257-260 med henvisninger; Pummer (2010), 5-8 med henvisninger; Ingrid Hjelm, "Mt. Gerizim and Samaritans in Recent Research", Mor \& Reiterer (2010), 25-41(32-33); Adam Zertal “The Province 
punkt, at samarisk Jahvisme er en oprindelig form for jahvedyrkelse, der udviklede sig parallelt med eller endda tidligere end jahvedyrkelsen i Yehud, stiller samaritanismen lige med jødedommen, og det afviser, at tidlig samaritanisme skulle være afhængig af tidlig jødisk tradition.

\section{Helligdommen på Garizim}

Garizim ligger syd for den moderne by Nablus (Neapolis i oldtiden) og det bibelske Sikem (Tell Balata). Det ligger ca. $30 \mathrm{~km}$ nord for Jerusalem og ca. $40 \mathrm{~km}$ øst for Middelhavet, og sammen med Ebal, som ligger mod nord, flankerer det Nablusdalen. Bjerget har tre tinder: Den højeste er Jebel-et-Tur (886 m), mod nord ligger Tell-er-Ras $(831 \mathrm{~m})$, og mod vest er der en bred bakkeskråning $(807 \mathrm{~m})$. Langt størstedelen af de arkæologiske fund på Garizim stammer fra Jebelet-Tur. Tell-er-Ras blev udgravet af Robert J. Bull i 1964, 1966 og 1968, og her fandt man resterne af et Zeustempel, der var opført i to faser. ${ }^{21}$ I 1929 foretog A. M. Schneider, en tysk arkæolog fra Göttingen, de første egentlige udgravninger på Jebel et-Tur. Schneider koncentrerede sig primært om den byzantinske kirke viet til Maria teotokos, der stammer fra det 5. årh. e.Kr. ${ }^{22}$ Fra 1982-2006 blev der foretaget omfattende udgravninger på Garizim under ledelse af Yitzhak Magen. Resultaterne af disse udgravninger er under udgivelse i

of Samaria (Assyrian Samerina) in the Late Iron Age (Iron Age III)", Judah and the Judeans in the neo-Babylonian Period, red. Oded Lipschitz \& Joseph Blenkinsopp (Winona Lake: Eisenbrauns 2003), 377-412; Yitzhak Magen, Mount Gerizim Excavations, Volume II. A Temple City (Jerusalem: JSP 2008a), 167. Bemærk Magens kritik af Zertal i note 4.

21. Jürgen Zangenberg, "The Sanctuary on Mount Gerizim: Observations on the Results of 20 Years of Excavation", Temple Building and Temple Cult. Studies on the Architecture and Cultic Paraphernalia of Temples in the Levant (2.-1. Millennium B.C.E.), ed. Jens Kamlah (Wiesbaden: Harassowitz 2012), 399-418; Robert J. Bull, "Ras, Tell er-", The Oxford Encyclopedia of Archaeology in the Near East, vol. IV, red. E. Meyers (Oxford: Oxford University Press 1997), 407-409; Magen (2008a), 3. Robert J. Bull var medlem af Drew-McCormick-ekspeditionen på Tell Balata, og hans udgravning på Tell er-Ras var en udløber af den ekspedition. Der findes ikke nogen endelig udgravningsrapport fra Tell er-Ras, men Bull udgav adskillige foreløbige rapporter og artikler, se henvisninger i Bull (1997). Den første dokumenterede udgravning på Tell er-Ras fandt sted allerede i 1866, og blev udført af Charles W. Wilson, se "Ebal and Gerizim", Palestine Exploration Fund 2 (1873), 66-71.

22. Alfons Maria Schneider, "Römische und Byzantinische Bauten auf dem Garizim”, ZDPV 68 (1951), 210-234; Robert J. Bull, "The Excavations of Tell er-Ras on Mt. Gerizim”, BA 31 (1968), 58-72, 61; Hjelm (2010b), 25; Zangenberg (2012). 
serien Judea and Samaria Publications (JSP), der udgives af The Israel Antiquities Authorities. Indtil videre er der udkommet to bind, der omhandler Garizim: Mount Gerizim Excavations Volume I (JSP 2) er den foreløbige udgivelse af de aramæiske, hebraiske og samaritanske indskrifter fra Garizim, og Mount Gerizim Excavations Volume II (JSP 8) indeholder en foreløbig udgravningsrapport over helligdommen og den by, der voksede op omkring den. Ifølge Magen er der planlagt yderligere tre bind, der skal supplere og uddybe de første to binds foreløbige resultater. ${ }^{23}$ Desuden kom der i 2012 en bog af Jan Dušek, der analyserer indskrifterne på Garizim, og i den forbindelse evaluerer Magens resultater. ${ }^{24}$ Den er et uvurderligt supplement til de indtil videre foreløbige udgravningsrapporter.

I løbet af Magens udgravninger på Garizim fandt man en Jahvehelligdom, der stammede fra persisk og hellenistisk tid, samt en by fra hellenistisk tid. Derudover udgravede man et sent romersk citadel, og foretog yderligere udgravninger af den førnævnte byzantinske teotokos-kirke og af Zeustemplet på Tell er-Ras (Magen 2007). Størstedelen af de materielle levn på stedet stammer fra den hellenistiske periode. Tempelområdet ligger under og rundt om teotokos-kirken, og det hellenistiske beboelsesområde ligger primært syd for helligdommen. ${ }^{25}$ Jahvehelligdommen er opført i to primære byggefaser: Den første fase, der stammer fra persisk tid, er opførslen af et tempelområde ca. i midten af det 5. årh. f.Kr. (Magen 2007, 180; 2008a, 103, 167). Denne struktur ligger på bjergets allerøverste punkt, og den er den $x$ ldste struktur, der er afdækket i løbet af de seneste udgravninger. Kun yderligere udgravning vil vise, om der findes ældre bygninger på bjerget. Helligdommen fra den persiske periode var i brug i ca. 250 år indtil den anden byggefase, som kan dateres til begyndelsen af det 2. årh. f. Kr. I løbet af Antiokus IIIs regeringstid (223-187) blev der bygget en helligdom og et nyt og større tempelområde ovenpå strukturerne fra persisk tid. Der er ingen tegn på, at bygningerne har

23. Magen (2008a), IX-X. Udover Mount Gerizim Excavations Volumes I and II har Magen udgivet resultater fra udgravningerne i en række artikler. Blandt disse anbefales særligt "The Dating of the First Phase of the Samaritan Temple on Mount Gerizim in Light of the Archaeological Evidence", Judah and the Judeans in the Fourth Century B.C.E., red. Oded Lipschits m.fl. (Winona Lake: Eisenbrauns 2007), 157-211. En komplet bibliografi findes i Magen (2008a).

24. Jan Dušek, Aramaic and Hebrew Inscriptions from Mt. Gerizim and Samaria between Antiochus III and Antiovhus IV Epiphanes (Leiden: Brill 2012).

25. Det har desværre ikke været muligt at få tilladelse til at gengive fotografier, grundplaner og tegninger fra Mount Gerizim Excavations I og II. Derfor må jeg henvise til illustrationerne i Magen (2008a). På side 7 findes en plan over hele det udgravede område (figur 4). 
været forladt i overgangen fra persisk til hellenistisk tid (Magen 2007, 157-166; 2008a, 97-203). Det ser tværtimod ud til, at man har gjort sig anstrengelser for at kunne fortsætte offerkulten på stedet, medens den anden byggefase stod på (Magen 2008a, 118).

Der knytter sig en interessant gåde til helligdommen på Garizim; det ligger fast, at der har været et kultsted viet til Jahve på stedet, og at dette kultsted har været i brug fra i hvert fald midten af det 5 . årh. f.Kr. og frem til 111-110 f.Kr. Men der er aldrig fundet en egentlig tempelbygning på Jebel et-Tur. Ifølge Magen var der en tempelbygning på Garizim i både den persiske og den hellenistiske periode, men resterne af disse er så godt som fuldstændig ødelagt på grund af heftig byggeaktivitet på byzantinsk tid. Den eneste undtagelse er den struktur, der i dag kendes som "de tolv sten", som Magen tolker som den eneste bevarede del af den oprindelige tempelbygning fra persisk tid (Magen 2008a, 113-114, 151-152). Ifølge samaritanernes egne overleveringer har der aldrig været en tempelbygning på Garizim. Josva stillede den mosaiske telthelligdom op på bjerget umiddelbart efter indvandringen i Kanaan, og der stod den, indtil den blev skjult i forbindelse med uenigheden over Elis illegitime helligdom i Shilo. ${ }^{26}$ På trods af fraværet af materielle levn fra en egentlig tempelbygning på Garizim er det sandsynligt, at helligdommen omfattede et "tempel". ${ }^{27}$ En af indskrifterne fra Garizim nævner, at en donation eller et offer blev givet "foran Herren i templet/helligdommen (bmqdš)", og en anden indskrift nævner et "offerhus/offertempel (bbyt $\left.d b h^{\prime}\right)^{\prime}$. Den sidstnævnte betegnelse bruges også om templet i Jerusa-

26. En fin gennemgang af det samaritanske materiale findes i Reinhard Pummer, "The Mosaic Tabernacle as the Only Legitimate Sanctuary: The Biblical Tabernacle in Samaritanism", The Temple of Jerusalem: From Moses to the Messiah. In Honor of Professor Louis H. Feldman, red. Steven Fine (Leiden: Brill 2011), 125-149. Se også Ingrid Hjelm, Jerusalem's Rise to Sovereignty: Zion and Gerizim in Competition (New York: T\&T Clark 2004a), 214-216; Yitzhak Magen, The Samaritans and the Good Samaritan (Jerusalem: Israel Antiquities Authorities 2008b), 151; Zangenberg (2012).

27. Helt generelt er bibelforskere alt for rigide, når det kommer til definitioner på templer og helligdomme. Sandheden er, at et tempel kan være mange forskellige ting, og at en "helligdom" sagtens kan udfylde et tempels funktioner, selvom den ikke nødvendigvis omfatter et hus. Se den glimrende præsentation af data i Ziony Zevit, The Religions of Ancient Israel: A Synthesis of Parallactic Approaches (London: Continuum 2001), 123ff. og Diana Edelman, "Cultic Sites and Complexes beyond the Jerusalem Temple", Religious Diversity in Ancient Israel and Judah, red. Francesca Stavrakopoulou \& John Barton (London: T\&T Clark 2010), 82-103. Og sammenlign med de græske eksempler i John Pedley, Sanctuaries and the Sacred in the Ancient Greek World (New York: Cambridge University Press 2005). 
lem i 2 Krønikebog 7,12. ${ }^{28}$ Selvom det ikke kan fastslås, at der var en egentlig tempelbygning på Garizim, kan det med sikkerhed siges, at der var et kultsted, der udførte præcis de samme funktioner som et tempel inklusiv en offerkult. Dette er hævet over enhver tvivl takket være de små 400 fragmenter af dedikationsindskrifter, der er fundet på stedet, samt den imponerende mængde af knogler og aske, der også er fundet der. ${ }^{29}$ Indtil videre er der udgravet mere end 300.000 knoglefragmenter fra får, geder, kvæg og duer (Magen 2008a, 160162).

Der er heller ingen tvivl om, at helligdommen på Garizim blev brugt til at tilbede Jahve. Det kan man udlede af dedikationsindskrifterne. ${ }^{30} \mathrm{Og}$ der er ingen tegn på, at andre guder end Jahve indgik i kulten på Garizim. I det hele taget synes offerkulten på Garizim at stemme overens med de rituelle love, vi kender fra Pentateuken; knoglefundene stammer fra tilladte offerdyr, billedforbuddet synes at have været overholdt, og det er muligt, at præsterne har haft deres eget aflukkede område (Magen 2008a, 141-164; Kartveit 2009, 257). ${ }^{31}$

Den by, der voksede op omkring helligdommen på Garizim, stammer fra hellenistisk tid. Den blev grundlagt i slutningen af det 4. årh. f.Kr., og den nåede sin videste udstrækning (ca. 400 dunam $=800$ $\mathrm{m}$ lang og $500 \mathrm{~m}$ bred) i det 2. årh. f.Kr. Da byen var på sit højeste, kan befolkningstallet have været op mod 10.000 indbyggere. ${ }^{32}$ Der er ganske få naturlige ressourcer på Garizim, og dermed ingen økonomiske årsager til at grundlægge en by på stedet. Det er sandsynligt, at

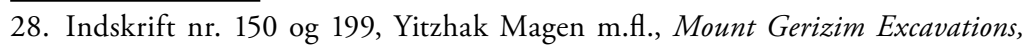
Volume I. The Aramaic Hebrew and Samaritan Inscriptions, JSP 2 (Jerusalem: Israel Antiquities Authorities 2004), 141, 171; Magen (2007), 168; Knowles (2004), 33.

29. For indskrifterne se Magen m. fl. (2004); Jan Dušek, Aramaic and Hebrew Inscriptions from Mt. Gerizim and Samaria between Antiochus III and Antiovhus IV Epiphanes (Leiden: Brill 2012), 3-63; Gudme (2013), 70-90.

30. Guddommen på Garizim kaldes Jahve ( $y h w h$, indskrift nr. 383), Herren ('dny) og Guden ('lh') (Magen m. fl. (2004), 22-23, 254).

31. I denne sammenhæng er det interessant at sammenligne med tekstfundene fra Elefantine, hvor vi har adskillige tekster, men intet bevis for, at Pentateuken har været kendt. Der er rituelle praksisser beskrevet i Elefantineteksterne, der matcher dele af Pentateuken ( $\mathrm{fx}$ de usyrede brøds fest - dog uden tilknytning til Pesach), og formodentlig også en offerkult med blodige ofre (se Kratz (2007), 82-89). Elefantineeksemplet demonstrerer, at ritualer, der stemmer overens med Pentateuken, ikke nødvendigvis er bevis for, at selve Pentateuken også har været kendt og brugt. Jeg tror umiddelbart, at bibelsk litteratur var kendt af Jahvedyrkerne på Garizim, men det er vigtigt at huske på, at vi ikke ved, hvor meget, hvornår og i hvilken form.

32. Magen (2008a), 177. Dette antal er blev kritiseret af Jürgen Zangenberg, som mener, at det er alt for højt (Zangenberg (2012)). Problemet er, at Magen ikke re$\operatorname{deg} ø \mathrm{r}$ for, hvordan han er nået frem til de 10.000, og det gør det vanskeligt at bedømme. 
byen blev grundlagt af religiøse årsager; helligdommen var der først, og byen udviklede sig rundt om helligdommen mere end et århundrede efter, at den var blevet grundlagt (Magen m.fl. 2004, 3; Magen 2008a, 3-8; 2007, 191-192). Ifølge SP-udgaven af Deut 27 befalede Jahve Josva at bygge et alter på Garizim, ikke på Ebal, og således er Garizim identificeret som Jahves udvalgte sted (Hjelm 2000, 92). ${ }^{33}$ I senere samaritanske traditioner bringer Josva åbenbaringsteltet til Garizim umiddelbart efter ankomsten i Kanaan (Pummer 2011). Det er sandsynligt, at byens nærmest eksplosive vækst i den hellenistiske periode skyldes Alexander den Stores ødelæggelse af hovedstaden, Samaria, i 332 f.Kr. Nogle af indbyggerne i Samaria kan være flyttet til Garizim efter Samarias fald (Magen 2008a, 98).

Byen var stort set ubefæstet, og den vidner ikke om nogen videre form for byplanlægning. Den ældste del af byen blev bygget syd for tempelområdet. Senere udvidedes byen mod sydvest, fordi terrænet var bedre der, og fordi man kom tættere på de frugthaver, der lå rundt om byen (Magen 2008a, 9-12, 89-90, 100). ${ }^{34}$ Både byen og helligdommen blev ødelagt af Johannes Hyrkan i 111-110 f.Kr. Efter ødelæggelsen forblev byen ubeboet. I begyndelsen af det 4. årh. e.Kr., i den byzantinske periode, blev dele af helligdommen genopbygget af samaritanerne, men i slutningen af det 5 . årh. blev hele området alvorligt beskadiget i forbindelse med opførelsen af teotokos-kirken (Magen 2007, 157-160; Magen m.fl. 2004, 1-3; Magen 2008a, 178).

\section{Helligdommen på Garizim ifølge Josefus}

På baggrund af Magens udgravninger på Tell er-Ras og Jebel et-Tur kan der drages to vigtige konklusioner angående religionshistorien på Garizim. For det første er det blevet slået fast, at resterne af det Zeustempel på Tell er-Ras, som Bull opdagede, ikke er det samaritanske tempel på Garizim. Templet består af to faser: Bygning A,

33. Det er sandsynligt, at SPs udgave er den oprindelige, simpelthen fordi det virker besynderligt at bygge det første alter i det forjættede land på forbandelsens bjerg, Ebal. Se Paolo Sacchi, The History of the Second Temple Period (Sheffield: Sheffield Academic Press 2000), 156.

34. Se Magen (2008a), 3-93 for en detaljeret gennemgang af de enkelte kvarterer i byen. Magen skriver godt nok: "the city grew mainly to the northwest because of the convenient lay of the land in that direction," [min kursivering] men i betragtning af hans tidligere beskrivelse, "the slopes south and west of the sacred precinct are relatively gentle, and it is here where most of the dwellings were built. On the northern slope construction was sporadic, due to the rough and fractured surface." (Magen (2008a), 9), er jeg overbevist om, at han mener sydvest. 
som Bull daterede til det 2. årh. e.Kr., og Bygning B, som lå under Bygning A, og blev dateret til det 4. årh. f.Kr. Bull gik ud fra, at Bygning B var det tempel, der ifølge Josefus (Ant 11.302ff., 13.255ff.; Bel 1.62ff.) blev bygget på Garizim af guvernøren Sanballat i løbet af Alexander den Stores regeringstid. ${ }^{35}$ Magen genudgravede Tell er-Ras, og nåede frem til den konklusion, at der ikke er tegn på byggeaktivitet tidligere end det 3. og 2. århundrede f.Kr. Bygning B var del af et romersk tempel, der stammede fra det 2 . årh. e.Kr., hvortil en senere fase blev tilføjet i det 3. årh. (Bygning A). ${ }^{36}$ Således er Bulls teori om et samaritansk tempel på Tell er-Ras blevet tilbagevist.

For det andet har man, nu hvor den første byggefase af helligdommen på Jebel et-Tur er dateret til det 5 . årh. f.Kr., endegyldigt kunnet tilbagevise, at templet på Garizim skulle være bygget på Alexander den Stores tid i overensstemmelse med Josefus' gengivelse af begivenhederne i passagerne, der er nævnt her ovenfor (Magen 2007, 180, 190-193; Pummer 2009, 38-43).

Årsagen til, at man valgte at opføre et jahvetempel på Garizim, præsenteres ofte med henvisning til Josefus' beretning om ægteskabet mellem datteren af den samaritanske (kutæiske) guvernør, Sanballat, og en præst fra Jerusalem ved navn Manasse (Ant 11.302-325). Manasse, som var bror til ypperstepræsten i Jerusalem, var i fare for at blive udelukket fra ypperstepræsteskabet på grund af ægteskab med en samaritansk kvinde, og derfor var han parat til at opgive forbindelsen. Men Manasses svigerfar lovede at bygge et tempel på Garizim og gøre Manasse til ypperstepræst der, hvis blot han ville gennemføre brylluppet (Pummer 2009, 107-119). Josefus skriver i Antiquitates 11.309-310:

Manasses went to his father-in-law Sanaballetes and said that while he loved his daughter Nikaso, nevertheless the priestly office was the highest in the nation and had always belonged to his family, and that therefore he did not wish to be deprived of it on her account. But Sanballetes promised not only to preserve the priesthood for him but also to procure for him the power and office of high priest and to appoint him governor of all the places over which he ruled, if he were willing to live

35. Bull (1997) med henvisninger; Bull (1968), 70-71; Zangenberg (2012); Magen (2007), 157, note 2 .

36. Magen (2008a), 157-158, 167, 174-175; Yitzhak Magen, Flavia Neapolis: Schechem in the Roman Period, Judea and Samaria Publications 5 (Jerusalem: Israel Antiquities Authorities 2005), 235-286, 253; Zangenberg (2012). 
with his daughter; and he said that he would build a temple similar to that in Jerusalem on Mount Garizein. ${ }^{37}$

Hvis man anser Josefus' beretning om grundlæggelsen af templet på Garizim for at være historisk korrekt, så skal begivenheden dateres til Alexander den Stores regeringstid, nærmere bestemt 332 f.Kr. (Schmidt 2001, 124). Men som også nævnt ovenfor er denne datering ikke længere sandsynlig, idet grundlæggelsen af templet på baggrund af de seneste udgravninger kan dateres til det 5. årh. f.Kr. (Magen 2007, 180, 190-193).

Magen mener, at de begivenheder, der lå til grund for opførslen af templet på Garizim, stemmer overens med Josefus' version i Antiquitates Bog 11, men at Josefus simpelthen fik galt fat i dateringen af disse begivenheder. Ifølge Magen er guvernøren Sanballat i Josefus' beretning i virkeligheden lig med "horonitten Sanballat", der nævnes i Nehemias' Bog 13,28, og som, igen ifølge Magen, levede på Nehemias' tid. Magen foreslår, at Josefus kan have forvekslet grundlæggelsen af templet på Garizim med grundlæggelsen af byen rundt om templet, som jo netop skete på Alexander den Stores tid, efter dennes ødelæggelse af Samaria (Magen 2007, 190-191). I Neh 13 bønfalder Nehemias Jahve om at huske på alle Nehemias' bedrifter og gode gerninger, og i forlængelse af en beskrivelse af de vanskeligheder, Nehemias har haft med de judæere, der giftede sig med fremmede kvinder (vv. 23-27), fortæller Nehemias om et konkret eksempel på dette, nemlig da han jagede en af ypperstepræstens sønner bort, fordi han havde besudlet præsteskabet ved at gifte sig med en udlænding: "En søn af Jojada, ypperstepræsten Eljashibs søn, var svigersøn til horonitten Sanballat; ham jog jeg bort fra mig”. På baggrund af dette mener Magen, at templet på Garizim blev grundlagt med templet i Jerusalem som forbillede, og at det blev bygget af "Jewish priests who followed the grandson of Eliashib, who was married to the daughter of Sanballat the Horonite (Neh 13:28)" (Magen 2008a, 149).

På denne måde placerer Magen sig midt imellem den såkaldt polemiske og apologetiske synsvinkel mht spørgsmålet om samaritanismens oprindelse. Magen mener, at tempelkulten på Garizim stammer fra Jerusalem (den polemiske synsvinkel), men han er ikke af den opfattelse, at indbyggerne i Samaria var efterkommere af udenlandske bosættere, der var blevet bragt til området af assyrerne. Han opfatter

37. Josephus VI, Jewish Antiquities Books IX-XI, The Loeb Classical Library (Cambridge: Harvard University Press 1987), 463-465. 
dem snarere som efterkommere af "Israel", bosat i Samaria (den apologetiske synsvinkel). ${ }^{38}$

Magen foreslår således, at både templet og tempelområdet i den første byggefase på Garizim var kopier af tilsvarende bygninger i Jerusalem. I den anden byggefase i hellenistisk tid udviklede der sig en lokal samaritansk byggetradition på Garizim, hvor helligdommen stadig var under indflydelse af templet i Jerusalem, uden dog at være en egentlig kopi af dette (Magen 2008a, 98).

\section{Helligdommen på Garizim i den persiske periode}

For at undersøge Magens påstand om sammenhængen mellem den første byggefase på Garizim og templet i Jerusalem er det nødvendigt at se nærmere på de arkæologiske levn på Jebel et-Tur, der stammer fra den persiske periode.

Den byggefase, der stammer fra persisk tid, er, som nævnt ovenfor, den ældste struktur, der er udgravet på Garizim. ${ }^{39}$ Helligdommen er grundlagt på et relativt stort og fladt plateau, som overfødiggjorde, at man huggede en platform ud af grundfjeldet (Magen 2008a, 97). Den første byggefase dateres til midten af det 5 . årh. f.Kr., og den ældste mønt, der er fundet på stedet, er en cypriotisk drakme, der kan dateres til 480 f.Kr. ${ }^{40}$ Fordelingen af mønter fra den persiske periode er dog temmelig usikker, fordi man først anvendte metaldetektorer i et sent stadie af udgravningen (Magen 2007, 179). ${ }^{41}$ Helligdommen fra den persiske periode var i brug i rundt regnet 250 år indtil ca. 200

$\overline{\text { 38. Magen (2008a) }}, 167-168$. I note 4 på side 167 skriver Magen: "Zertal's claim that the wedge decorations are evidence for the existence of peoples brought by the Assyrian king and settled in Samaria is unacceptable. Furthermore, we do not accept Zertal's use of the term 'Cuthaean' for these peoples." Jf. Hjelm (2005), 163-164.

39. For nogle år siden foreslog Yitzhak Magen og Ephraim Stern, at fundet af en proto-æolisk kapitæl på Garizim kunne indikere en byggefase, der stammer fra jernalderen. I en senere artikel skriver Magen dog, at de arkæologiske levn på Garizim ikke understøtter denne teori (Ephraim Stern \& Yitzhak Magen, "Archaeological Evidence for the First Stage of the Samaritan Temple on Mount Gerizim", Israel Exploration Journal 52 (2002), 49-57; Magen (2008a), 97-98, 168). Magen (2008a, 152-153) foreslår i stedet, at kapitælen hører til I den byggefase, der stammer fra persisk tid.

40. Magen (2008a), 167-171. Jan Dušek (2012, 3-4) mener, at den første byggefase skal dateres til Darius IIs regeringstid (424-405) i den sidste tredjedel af det 5. årh., snarere end ca. 450 f.Kr..

41. Når man tager forekomsten af proto-æoliske kapitæler, sekskammerporte, og udgravningsrapportens ufærdige karakter i betragtning, er det klart, at konklu- 
f.Kr., da området blev udvidet betragteligt, og adskillige bygninger, gårdspladser og trapper blev tilføjet. I den persiske periode målte tempelområdet $96 \mathrm{~m}$ fra nord til syd og $98 \mathrm{~m}$ fra øst til vest, men i den hellenistiske periode strakte det sig $212 \mathrm{~m}$ fra nord til syd og $136 \mathrm{~m}$ fra øst til vest (Magen 2008a, 103, 143).

I den persiske periode var tempelområdet en relativt lille og firkantet struktur, der var bygget af kampesten. Den bestod af en ydermur, hvoraf vestsiden er den bedst bevarede, og en række mindre rum og gårdspladser indenfor muren. Desuden forestiller Magen sig, at der har været en aflang tempelbygning, orienteret mod øst, og med en bagvæg, der lå tæt på den vestlige del af ydermuren (Magen 2008a, 99-100, figur 180 og 181). Tempelbygningen vil jeg vende tilbage til her nedenfor. Sammenlignet med den yngre struktur fra hellenistisk tid er tempelområdet fra den persiske periode småt og temmelig skrabet.

Ifølge Magen er det ganske let at skelne de to byggefaser fra hinanden, fordi man i den persiske periode udelukkende har bygget med kampesten i modsætning til den hellenistiske periode, hvor der er anvendt kvadersten. Desuden er der anvendt forskellige former for puds i de to faser (Magen 2008a, 103, 117). I den persiske periode havde tempelområdet mindst to porte; en mod nord og en mod syd. Den nordlige port blev fuldstændig blotlagt under udgravningerne, hvorimod kun ganske lidt af den sydlige port er bevaret. Der er ikke fundet nogen spor efter en østlig port i helligdommens ydermur, men Magen mener alligevel, at der har været en østport, som blev fuldstændig ødelagt i forbindelse med den anden byggefase (Magen 2008a, 98-100, 103, 143, figur 266). Denne formodede østlige port vil jeg vende tilbage til.

Områdets nordlige port var sandsynligvis den ene af helligdommens to hovedindgange i den første byggefase, fordi den vender ud mod hovedvejen til Sikem. Den anden hovedindgang må have været den sydlige port, fordi den forbandt tempelområdet med de ældste dele af byen på Garizim (Magen 2008a, 100-102). I den hellenistiske periode blev nordporten, som var en seks-kammer port, skilt ad og dækket til, og en anden fire-kammer port blev bygget i muren lidt længere mod vest (Magen 2008a, 117). Sydporten blev også skilt ad i den hellenistiske periode, og idet man udvidede hele området $\mathrm{i}$ en sydlig retning, flyttede man porten fra syd til vest (Magen 2008a, 103).

sioner angående dateringen af de ældste strukturer på Garizim kun kan være foreløbige og tentative (Hjelm (2010a); Stern \& Magen (2002); Zangenberg (2012)). 
Den østlige side af tempelområdet ender i en skråning, der ligger lige uden for muren. I den hellenistiske periode byggede man en firekammer-port og en rampe eller trappe, der førte op til porten. Der er afdækket nogle støttemure fra den persiske periode, der grænser op til støttemure fra den hellenistiske periode, så det kan ikke udelukkes, at der har været en lignende rampe eller trappe udenfor østmuren allerede i den persiske periode. Men som nævnt ovenfor er der ikke fundet nogen spor af en østport fra den persiske periode, og ifølge Magen var netop denne del af udgravningerne plaget af alvorlige stratigrafiske vanskeligheder, hvilket umuliggjorde en detaljeret redegørelse for østmurens udvikling i den persiske og tidlige hellenistiske periode (Magen 2008a, 120). På trods af de manglende beviser for en østport rekonstruerer Magen tempelområdet fra den persiske periode som en helligdom med tre porte. Han foreslår, at den østlige port først og fremmest blev anvendt ved ceremonielle lejligheder i helligdommens første byggefase, fordi den på det tidspunkt var vanskeligt tilgængelig (Magen 2008a, 98-102).

Midt på den plads, der støder op til den hellenistiske østport, har man fundet et stenalter, dækket med pudsekalk. Alteret blev fundet ved foden af porten, og derfor stammer det sandsynligvis fra den persiske periode. Hele pladsen var dækket med pudsekalk, og store mængder aske og dyreknogler blev fundet rundt om alteret (Magen (2008a, 120-122).

Den bedst bevarede struktur fra den persiske periode er tempelområdets vestlige mur. Der er fundet rester af en vestmur fra både den persiske og den hellenistiske periode, men hvor den hellenistiske mur næsten er væk på grund af byggeaktivitet i senere perioder, er den persiske mur overraskende velbevaret. Det ville have været indlysende at bygge en port i denne del af muren, fordi området er lettilgængeligt fra vestsiden, men Magen mener, at man undlod at bygge en indgang i vestmuren, fordi den lå tæt på selve tempelbygningens inderste rum, det "allerhelligste" (Magen 2008a, 110-114). Vestmuren fra den persiske periode er bevaret i sin fulde længde. Den er 83,7 m lang, 1,3 $\mathrm{m}$ bred, og nogle steder er den bevaret i en højde helt op til to meter.

Udover murene og de to porte har man langs med vestmuren, i områdets sydvestlige hjørne, fundet en bygning, der måler $12 \times 21,5$ $\mathrm{m}$. Bygningen bestod af en stor gårdsplads med et rum på hver side. Gulvene i de to rum og på gårdspladsen var af stampet jord, dækket med et tyndt lag kalk, og der blev fundet keramik og mønter fra den persiske periode i bygningen, samt dyreknogler, der kunne stamme fra offerdyr. I tempelområdets nordvestlige hjørne fandt man endnu en gårdsplads med keramik fra den persiske periode (Magen 2008a, 
110). Det ser ligeledes ud til, at der har været små rum langs med nord- og østmuren (Magen 2008a, 110-122).

En anelse øst for tempelområdets vestmur findes den førnævnte struktur, "de tolv sten". Strukturen er firkantet, bygget af store tilhuggede kampesten, og måler 6,5 x $18 \mathrm{~m}$. Magen foreslår, at denne struktur er det eneste levn fra den tempelbygning, der har stået i tempelområdet i den persiske periode, og at "de tolv sten" har været en del af templets "allerhelligste" i den første byggefase. Strukturen blev ikke skilt ad i den hellenistiske periode, muligvis på grund af dens hellighed (Magen 2008a, 113-114; Zangenberg 2012).

I den byggefase på Garizim, der stammer fra persisk tid, har vi altså en velbevaret vestmur med en bygning i det sydvestlige hjørne og en delvist bevaret gårdsplads i det nordvestlige hjørne. Den nordlige port er bevaret i sin helhed. Det samme gælder den vestlige ende af tempelområdets nordmur. Der er kun ganske få levn fra områdets sydport, og der er så godt som intet bevaret af den sydlige mur. Der er praktisk talt intet bevaret af østmuren, og der er ingen spor af en eventuel østlig port fra den persiske periode. Til slut synes der at være tegn på, at der har været nogle rum i områdets nordøstlige hjørne, og så har der muligvis stået et alter ved siden af det sted, hvor den hellenistiske østport senere blev bygget. De arkæologiske levn fra den persiske periode giver ikke noget endegyldigt bevis for, at der har været en egentlig tempelbygning på Garizim, medmindre man accepterer Magens fortolkning af "de tolv sten" som den vestlige del af netop en sådan bygning.

\section{Templet på Garizim og templet på Jerusalem}

Lad os nu vende tilbage til Magens påstand om, at templet på Garizim i den persiske periode er bygget med templet i Jerusalem som forbillede. Denne konklusion når Magen frem til på baggrund af Josefus' beretning om ypperstepræsten af Jerusalems bror, der giftede sig med en kvinde fra Samaria og fik sit eget tempel, kombineret med Nehemiasbogens omtale af horonitten Sanballat. Magen indrømmer, at vores viden om templet i Jerusalem er begrænset, dels på grund af manglende arkæologisk materiale, dels på grund af manglende historiske kilder. Ikke desto mindre forsøger han sig med en rekonstruktion af templet $\mathrm{i}$ Jerusalem på baggrund af tempelvisionen i Ezekiels Bog, Mishnatraktaten Middoth, Tempelrullen og Aristeas- 
brevet (Magen 2008a, 141-149). ${ }^{42}$ Det er Magens sammenligning med templet i Ezekiels Bog, der er mest relevant for helligdommen på Garizim i den persiske periode, så det er den, jeg vil koncentrere mig om i det følgende.

Ezekielbogens vision om det nye tempel i Jerusalem accepteres ikke af alle som en pålidelig kilde til Jerusalemtemplets udseende i den tidlige persiske periode. Der er flere, der anser Ezekiels beskrivelse af det ideelle tempel som en rent litterær konstruktion, eller som Michael Owen Wise har døbt det, "a midrashic temple" ${ }^{43}$ Ezekiels tempelvision kan fungere som rettesnor for en bestemt forståelse af helligt rum, men den kan ikke bruges som grundplan for en egentlig tempelbygning. Dette skyldes rent praktisk, at teksten udelukkende beskriver templet i to dimensioner, og mere overordnet, at Ezekiels Bog er et ideologisk skrift, der er gennemsyret af forestillinger om den ideelle virkelighed, snarere end en interesse for virkeligheden som sådan. ${ }^{44}$

På trods af disse forbehold bør vi se nærmere på Magens sammenligning mellem Ezekiels tempelvision og den første byggefase på Garizim.

Ezekiels tempel består af to gårdspladser. Både den indre og den ydre gård har tre porte, en mod øst, en mod nord og en mod syd. I den inderste gård er der adskillige rum, der benyttes af levitterne og andre tempeltjenere (Ez 40,1-42,20). Brændofferalteret står foran indgangen til tempelbygningen (40,47; 43,13-27), og templet vender mod øst $(47,1)$. I Ezekiel 43 kommer Jahves herlighed til syne i øst, og den kommer ind i templet gennem den østlige port $(43,1-5)$. Derfor skal østporten altid holdes lukket. Kun fyrsten må benytte den på sabbatten og på nymånedagen og andre festdage (44,1-3; 46,1-12).

Magen påpeger, at både Garizimtemplet og Ezekiels tempel er orienteret mod øst, og at ingen af templerne har en port, der vender mod vest, formodentlig fordi en sådan ville være for tæt på templernes “al-

42. For en diskussion af muligheden for at rekonstruere Jerusalemtemplet i den persiske periode på baggrund af bibelske tekster se Diana Edelman, "What Can We Know about the Persian-Era Temple in Jerusalem?", Temple Building and Temple Cult. Studies on the Architecture and Cultic Paraphernalia of Temples in the Levant (2.-1. Millennium B.C.E, red. Jens Kamlah (Wiesbaden: Harassowitz 2012), 343368, som anbefaler en rekonstruktion på baggrund af 1 Kong 6 og 2 Krøn 1-5.

43. Michael O. Wise, A Critical Study of the Temple Scroll from Qumran Cave 11 (Chicago: The Oriental Institute of the University of Chicago 1990), 199.

44. Edelmann (2012); Zangenberg (2012); Robert P. Carroll, "So What Do We Know About the Temple? The Temple in The Prophets", Second Temple Studies. 2. Temple and Community in the Persian Period, red. Tamara C. Eskenazi \& Kent H. Richards (Sheffield: Sheffield Academic Press 1994), 34-51, 44-45; Mark K. George, Israel's Tabernacle as Social Space (Atlanta: Society of Biblical Literature 2009), 102-105; Kalinda R. Stevenson, The Vision of Transformation: The Territorial Rhetoric of Ezekiel 40-48 (Atlanta: Society of Biblical Literature 1996), 4-5. 
lerhelligste” (Magen 2008a, 146). Begge disse iagttagelser er naturligvis korrekte, men man bør erindre, at der faktisk ikke er fundet nogen tempelbygning på Garizim, og at en sådan bygnings orientering derfor kun kan være hypotetisk. Desuden er en øst-vest-orientering så almindelig, at den næppe i sig selv kan bruges til særlig meget.

Magens næste skridt er at koncentrere sig om en sammenligning af placeringen af portene i Ezekiels tempel og i helligdommen på Garizim. Ifølge Ezekiel 46,9 er templets syd- og nordport hovedsagligt til brug for folket. Det er også her, vi får den lidt besynderlige oplysning, at man skal gå ud gennem nordporten, hvis man er kommet ind ad sydporten og vice versa, fordi det er forbudt at forlade templet samme vej, som man kom ind. Ezekiels beskrivelse af nord- og sydporten som folkets porte stemmer godt overens med Magens fortolkning af nord- og sydporten på Garizim, som vender ud mod henholdsvis hovedvejen til Sikem og de ældste dele af byen syd for tempelområdet (Magen 2008a, 100-102; 147).

Magen tolker også den formodede østport på Garizim i lyset af østporten i Ezekiels tempel. Han skriver, at den formodentlig blev brugt ved ceremonielle lejligheder, og at den formodentlig var forbeholdt guvernøren af Samaria. Desuden udlægger Magen det alter fra den persiske periode, der blev fundet under den hellenistiske østport på Garizim, som et bevis for, at der blev ofret slagtofre indenfor østporten i overensstemmelse med beskrivelsen i Ezekiels Bog. Der er to problemer med denne fortolkning. For det første kan man i Ezekiels Bog 46 læse, at fyrsten skal vente i østporten, mens præsterne ofrer hans medbragte slagtofre på hans vegne:

Så skal fyrsten komme gennem portens forrum udefra og stille sig ved dørstolpen, og mens præsterne ofrer hans brændoffer og hans måltidsoffer, skal han tilbede på portens tærskel. Så skal han gå ud, og porten skal ikke lukkes før aften (v. 2).

Men det fremgår ikke noget sted i Ezekiel, at fyrstens slagtofre skal ofres noget andet sted end på brændofferalteret, og derfor giver Ezekiels Bog os ingen grund til at antage, at der var endnu et alter, der stod i nærheden af østporten. Der er altså ingen grund til at gå ud fra, at det alter, der blev fundet under den hellenistiske østport på Garizim, ikke er identisk med det centrale brændofferalter i helligdommen i den persiske periode. Særligt ikke i betragtning af, at det må have befundet sig lige ud for indgangen til tempelbygningen, hvis Magen da har ret i sin rekonstruktion af denne. Magen opfinder således en port, der tilsyneladende ikke er der i den persiske periode, og desuden opfinder han et (ekstra) brændofferalter, der, så vidt vi 
ved, heller ikke er der, og stiller dette alter foran en østvendt tempelbygning, som muligvis heller aldrig har været der. Det virker slet ikke usandsynligt, synes jeg, at "de tolv sten" virkelig er en del af en tempelbygning, der engang har stået på Garizim. Det er vanskeligt at be- eller afvise. Men jeg kan ikke se, hvordan man på baggrund af det forhåndenværende materiale på Garizim, kan rekonstruere et brændofferalter midt i tempelgården. Det eneste alter, man har fundet, befinder sig lige indenfor østmuren.

For det andet må det understreges, at selvom Magens rekonstruktion af østporten og hans teori om dens funktion, virker overbevisende, så er der i realiteten ikke fundet nogen spor af en østport, der stammer fra persisk tid, på Garizim. Magens påstand om, at tempelområdet på Garizim havde tre porte i den første byggefase, er kun en hypotese, og oven i købet en hypotese, der synes mere end en anelse påvirket af en læsning af Ezekiels Bog.

\section{Konklusion}

En kritisk evaluering af de persiske levn på Garizim viser, at der på baggrund af disse ikke er belæg for Magens påstand om, at templet på Garizim blev bygget af jødiske præster, der fulgte ypperstepræsten Eliashibs sønnesøn, horonitten Sanballats svigersøn, til Samaria. Og at dette tempel blev bygget med templet i Jerusalem som forbillede. Et tempel, der svarer til beskrivelsen af templet i Ezekiels Bog (Magen 2008a, 149).

Ezekiels tempelvision er sandsynligvis ikke den mest pålidelige kilde til Jerusalemtemplet i den persiske periode, men selv hvis vi ser bort fra dette forbehold, er der intet i det arkæologiske materiale fra persisk tid på Garizim, der underbygger at templet i Ezekiels Bog skulle have fungeret som inspiration for helligdommen på Garizim.

Der er de helt åbenlyse forskelle, såsom at Ezekiels tempel har to gårdspladser, og at helligdommen på Garizim kun har en. Og så er der naturligvis det endnu ubesvarede spørgsmål, om der nogensinde har været en egentlig tempelbygning på Garizim. Hvis svaret er nej, bliver en sammenligning med gammeltestamentlige beskrivelser af tempelbygninger i det hele taget naturligvis mindre oplagt. Men udover disse indvendinger er der et andet, langt mere grundlæggende, problem med Magens konklusioner angående helligdommen på Garizim, nemlig at de arkæologiske levn fra den persiske periode simpelthen ikke er tilstrækkelige til at retfærdiggøre, at templet på Garizim skulle være bygget med et tempel, der minder om Ezekiels 
tempel, som forbillede. Der er ingen spor af en østport, og så godt som ingen rester af sydporten eller den østlige og den sydlige mur. Man kunne faktisk gå så langt som til at sige, at hvis man ikke forinden havde læst beskrivelsen af templet i Ezekiels Bog, så ville man aldrig på baggrund af det foreliggende arkæologiske materiale fra den persiske periode på Garizim være nået frem til en rekonstruktion af helligdommens første byggefase, der minder om den, Magen har foreslået. Der er således ikke arkæologisk bevis for, at helligdommen på Garizim blev bygget med templet i Jerusalem som forbillede.

Det vil sige, at den begrænsede viden, vi har, om Garizimhelligdommens udseende i den persiske periode ikke kan bruges som et argument for den polemiske synsvinkel, som jeg refererede i begyndelsen af denne artikel. Den kan på den anden side heller ikke bruges som et forsvar for den apologetiske synsvinkel, fordi det ville være at argumentere på baggrund af et fravær, et argumentum ex silentio.

Det ser således ud til, at vi må lede et andet sted efter svaret på spørgsmålet om samaritanismens, eller den nordlige jahvedyrkelses, oprindelse. Resterne af Jahvehelligdommen på Garizim vidner ikke i sig selv om en afhængighed af Jerusalem. 